\title{
КРИМІНАЛЬНА ПРОЦЕСУАЛЬНА РЕСТИТУЦІЯ ЯК СПОСІБ ВІДШКОДУВАННЯ ПОТЕРПІЛОМУ ШКОДИ, ЗАВДАНОӤ КРИМІНАЛЬНИМ ПРАВОПОРУШЕННЯМ
}

\author{
ЦИЛЮРИК ІнНа - кандидат юридичних наук, доцент кафедри кримінального \\ права і процесу Інституту права, психології та інноваційної освіти Національного \\ університету «Львівська політехніка" \\ ORCID ID: https://orcid.org/0000-0002-4776-2278 \\ DOI 10.32782/LAW.UA.2021.4.14
}

У статті розглянуто поняття «реституизія» як спосіб відшкодування шкоди потерпілому. Визначено, щзо чинний КПК не надає визначення изого поняття, однак ми наголошуємо, шо реституиія як спосіб відшкодування шкоди потерпілому отримала своє законодавче закріплення вже в периих юридичних актах радянсъкої держави. Саме тому реституція представляе собою найбільи простий спосіб захисту порушених майнових прав потерпілого. 3 ї̈ допомогою законодавець розраховує оперативно відновити майновий status quо, у якому особа знаходилася до вчинення злочину проти ней. Термін «реституція» знайшов своє нормативне закріплення $і$ на рівні міжнародних документів. Декларація містить окремий розділ (статті 8 - 11), присвячений реституиї. Згідно зі ст. 8 Декларациї реституція повинна включати повернення власності або виплату за спричинені збитки чи шкоду, відшкодування витрат, спричинених віктимізаијєю, надання послуг та поновлення у правах Проаналізовано законодавство Великої Британї $i$ США, у якому визначено реституиію як повернення незаконно набутого майна, ремонт пошкодженого або повернення в натурі еквівалента знищеного майна. Цікавим вбачається підхід, який використав законодавець Республіки Молдова. Так, у КПК иієї держави окремо виділяються дві статті, які стосуються рішення щодо речових доказів, що виносяться до основного розгляду кримінальной справи, і рішення, що приймаються під час вирішення кримінальної справи по суті.
Це дає змогу говорити, що варто впровадити в чинний КПК нормативний припис щодо можливості застосування кримінальної проиесуальної реституий на стадії досудового розслідування за умов, якщо на об'єктах злочинного посягання відсутні сліди кримінального правопорушення та є клопотання потерпілого про повернення йому майна.

Ключові слова:реституиія, кримінальне правопорушення, завдання шкоди, потерпілий, майно.

Постановка проблеми

Тривалий час термін «реституція» використовувався переважно у сферах міжнародного та цивільного права. Проте він має прямий стосунок до кримінальної процесуальної діяльності, де вже посів особливе місце серед способів відшкодування шкоди потерпілому.

Чинний КПК не надає визначення цього поняття, однак наголосимо, що реституція як спосіб відшкодування шкоди потерпілому отримала своє законодавче закріплення вже в перших юридичних актах радянської держави. Так, слід звернути увагу на ст. 58 Положення про військових слідчих № 1559 від 30.09.1919 р., де було закріплено: предмети, викрадені або відняті, після відшукання їх, повертаються під розписку тим, у кого були викрадені або відняті, якщо в залученні їх до справи немає необхідності [1, с. 108].

У подальшому зміст цієї статті знайшов своє відображення в п. 5 ч. 9 ст. 100 чинного КПК, де зазначено, що «питання про... 
долю речових доказів і документів, які були надані суду, вирішується судом під час ухвалення судового рішення, яким закінчується кримінальне провадження. У разі закриття кримінального провадження слідчим або прокурором питання про...долю речових доказів і документів вирішується ухвалою суду на підставі відповідного клопотання. При цьому гроші, цінності та інше майно, що були предметом кримінального правопорушення або іншого суспільно небезпечного діяння, конфіскуються, крім тих, які повертаються власнику (законному володільцю), а якщо його не встановлено - переходять у власність держави в установленому Кабінетом Міністрів України порядку».

\section{Аналіз останніх досліджень і публікацій}

Безумовно, питання кримінальної процесуальної реституції не залишено без уваги i науковцями. Питання визначення процесуального становища потерпілого в кримінальному провадженні та відшкодування йому шкоди неодноразово перебували у центрі уваги таких відомих процесуалістів, як Ю.П. Аленін, С.А. Альперт, В.П. Бож'єв, В.Г. Буткевич, А.В. Брусніцин, М.I. Гошовський, Ю.М. Грошевий, К.Ф. Гуценко, С.В. Давиденко, Т.М. Добровольська, П.С. Елькінд, 3.З. Зінатуллін, Х.Р. Кахнич, Л.Д. Кокорєв, В.М. Кудрявцев, О.П. Кучинська, О.М. Ларін, П.А. Лупинська, В.Т. Маляренко, О.Г. Мазалов, А.^. Нескороджена, B.T. Нор, I. А. Петрухін, Т.I. Присяжнюк, В.Я. Понарін, В.М. Савицький, М.С. Строгович, I.А. Тітко, Н.Б. Федорчук та ін.

\section{Виклад основних положень}

Передусім слід сказати, що реституція як спосіб відшкодування шкоди потерпілому визнається не всіма вченими - процесуалістами.

У юридичній літературі висловлюються думки щодо виключно компенсаційного (замісного) характеру інституту відшкодування шкоди, і кримінальна процесуальна реституція не належить до способів такого відшкодування. Так, В.Т. Нор, розглядаючи питання розмежування способів відшкодування шкоди та реституції у кримінальному про- цесі, наголошує на наступному: якщо майно, яке вибуло з володіння потерпілого внаслідок злочину, є в натурі, не пошкоджене і законний власник має можливість отримати його назад, як це має місце при реституції, то суб'єктивне право власника на це майно не втрачається, і говорити про заподіяння майнової шкоди в такому випадку було $б$ неправильно. Відшкодування шкоди, у свою чергу, передбачає не повернення втраченого майна, а відшкодування завданих збитків або передачу потерпілим особам майна того самого роду і якості замість знищеного, пошкодженого майна або такого, що невідомо, де знаходиться [2, с. 153].

На нашу думку, все ж таки не слід виключати кримінальну процесуальну реституцію iз переліку способів відшкодування шкоди у кримінальному процесі, оскільки, якщо вважати, що у разі повернення власнику викраденого майна, не відбулося заподіяння майнової шкоди, слідчий або прокурор мусять виносити вмотивовану постанову про відмову у визнанні потерпілим у зв'язку 3 відсутністю шкоди відповідно до ч. 5 ст. 55 КПК. Отже, факт завдання шкоди потерпілому має встановлюватися незалежно від повернення або місцезнаходження майна, яке було предметом злочинного посягання, через що і реституцію з упевненістю слід зарахувати до способів відшкодування шкоди потерпілому.

Реституція (лат. «restitutio») означає «відновлення початкового становища», «повернення втраченого», «відшкодування збитків, шкоди» [3, с. $877-878]$.

Як вважають науковці, реституція представляє собою найбільш простий спосіб захисту порушених майнових прав потерпілого. 3 її допомогою законодавець розраховує оперативно відновити майновий status quo, у якому особа знаходилася до вчинення злочину проти неї [2, с. 153].

Законодавець не враховує очевидні переваги реституції перед іншими способами відшкодування завданої злочином шкоди, оскільки ні КПК 1960 р., ні чинний КПК не містять спеціального розділу, окремих статей, які були $б$ присвячені поняттю «кримінальна процесуальна реституція» та порядку їі здійснення. 


\section{Кримінальне право, кримінальний процес та криміналістика}

Нормативне використання досліджуваного терміна наразі найбільш поширене в цивільному праві і означає повернення сторін у початкове становище через визнання правочину недійсним. Відповідно до ч. 1 ст. 216 ЦК у разі недійсності правочину кожна із сторін зобов'язана повернути другій стороні у натурі все, що вона одержала на виконання цього правочину, а якщо немає такої можливості, наприклад, коли одержане полягає у користуванні майном, виконаній роботі, наданій послузі, то відшкодувати вартість того, що одержано, за цінами, які існують на момент відшкодування.

Термін «реституція» знайшов своє нормативне закріплення і на рівні міжнародних документів. Декларація містить окремий розділ (статті 8 - 11), присвячений реституції. Згідно зі ст. 8 Декларації реституція повинна включати повернення власності або виплату за спричинені збитки чи шкоду, відшкодування витрат, спричинених віктимізацією, надання послуг та поновлення у правах [4].

Отже, як видно із викладеного, у міжнародному праві реституція - це поняття загальне, що включає в себе і повернення власності в натурі, і виплату за спричинену шкоду.

Законодавство Великої Британії і США визначає реституцію як повернення незаконно набутого майна, ремонт пошкодженого або повернення в натурі еквівалента знищеного майна. Зміст реституції складають такі дії, як повернення та відновлення вкрадених речей на користь їх законного власника, виплата суми, що не перевищує вартості вкрадених речей, передача жертві речей, які є прямими чи непрямими доходами, отриманими в результаті реалізації вкрадених речей [5, с. 78]. Слід відмітити, що в законодавстві багатьох країн реституція за своїм змістом співпадає 3 інститутом цивільного позову в Україні. Так,Г.Й. Шнайдер з цього приводу вказує, що в державах Східної та Північної Европи (Hiдерланди, Данія, Швеція і ін..) діють правила реституції, які включають у себе розгляд позову за правилами цивільного судочинства [6, с. 304].
У чинному кримінальному процесуальному законодавстві України реституція як спосіб відшкодування шкоди означає лише повернення предметів, речей, документів, цінностей, що вибули із законного володіння особи внаслідок кримінального правопорушення (п. 5 ч. 9 ст. 100 КПК).

У наведеному нормативному положенні йдеться лише про предмет кримінальної процесуальної реституції - гроші, цінності та інше майно, що були предметом кримінального правопорушення або іншого суспільно небезпечного діяння. Дефініції терміна «кримінальна процесуальна реституція» закон не містить. У той же час, як справедливо наголошує В.Т. Нор, у главі 9 КПК «Відшкодування шкоди у кримінальному провадженні» про цей спосіб відшкодування окремо не згадується. Проте він реально існує, використовується у провадженні на підставі п. 5 ч. 9 ст. 100 КПК,ч. 4 ст. 374 КПК, широко застосовується на практиці. Тож, він має бути закріплений у ст. 127 КПК, яка визначає способи відшкодування (компенсації) шкоди потерпілому [2, с. 38]. Крім цього, законодавець має роз'яснити потерпілому зміст та порядок реалізації цього способу відшкодування шкоди.

На основі наведеного вище можна дійти висновку, що зміст реституції в міжнародному праві не відповідає змісту однойменного поняття в кримінальному процесі України. В обох випадках реституція спрямована на відновлення порушених прав потерпілого. Однак у міжнародному праві реституція разом із відшкодуванням шкоди в натурі включає в себе і грошову компенсацію, що у вітчизняному кримінальному процесі належить до інституту цивільного позову в кримінальному провадженні, а реституція передбачає лише повернення незаконно вилученого майна.

Сучасні автори звертають увагу на те, що наукових досліджень, присвячених реституції у кримінальному процесі, не багато [7, с. 16].У той же час у науці не вироблена єдина думка стосовно таких питань, як: 1) правова природа реституції; 2) кримінальна процесуальна реституція як спосіб відшкодування майнової та моральної шкоди; 3) порядок їі 
здійснення та часові межі реалізації даного інституту.

У науці кримінального процесу проблема правової природи реституції як способу відшкодування шкоди потерпілому не знайшла свого єдиного вирішення. Так, В.Я. Понарін визнає кримінально-процесуальний характер реституції та наголошує на тому, що слід використовувати термін «кримінальнопроцесуальна реституція», під якою розуміє відновлення майнового становища особи, потерпілої від злочину, шляхом повернення їй в порядку, визначеному законом, речових доказів, а за необхідності - предметів того ж роду і якості або сплати їх вартості, якщо це можливо [8, с. 45].

На тому, що реституція, яка здійснюється в кримінальному процесі, по своїй природі є кримінально-правовою наполягає і3.3. Зінатуллін. До того ж додамо, що науковець розуміє іiі як відновлення майнового становища потерпілого шляхом повернення йому речей або інших матеріальних цінностей, які були безпосередньо втрачені в результаті вчинення злочину [9, с. 29].

Термін «кримінально-правова реституція» застосовує також В.Т. Нор, розглядаючи її як відновлення порушеного злочином майнового становища потерпілого шляхом повернення йому неправомірно відчуженого майна - речових доказів, виявлених, вилучених або прийнятих від інших осіб органами, що ведуть кримінальний процес [2,c. 153].

Проте інші вчені, серед яких С.О. Александров, Б.Т. Безлепкін, мають діаметрально протилежну точку зору стосовно визначення правової природи реституції в кримінальному процесі. Так, вони вважають, що реституція має називатися саме кримінально-процесуальною, оскільки застосовується в кримінальному процесі [10, с. 28 - 29].

Крім наведеної класифікації точок зору на визначення питання «правова природа реституції в кримінальному провадженні», слід навести і іншу, яка також заслуговує на увагу.

3 огляду на важливість єдиного розуміння одного і того ж терміна, вважаємо за доцільне зробити висновок, що правова природа реституції в кримінальному процесі є кримінальною процесуальною. На підтримку цього положення можна навести такі аргументи.

На наш погляд, реституція в кримінальному процесі забезпечує виконання завдань кримінального провадження, а саме: захист особи від кримінальних правопорушень, охорона прав, свобод та законних інтересів учасників кримінального провадження(ст. 2 КПК).

По-друге, при здійсненні реституції реалізуються кримінальні процесуальні правовідносини. Тобто правовідносини, що стосуються відшкодування шкоди потерпілому за допомогою кримінальної процесуальної реституції, які виникають, розвиваються і припиняються у сфері кримінального процесу.

Отже, пропонуємо визначення, яке, на нашу думку, $є$ найбільш обгрунтованим: кримінальна процесуальна реституція - це спосіб відновлення майнового стану потерпілого, який полягає у поверненні речей або інших матеріальних цінностей, які були вилучені з його безпосереднього законного володіння або користування в результаті вчинення кримінального правопорушення або іншого суспільно небезпечного діяння, що здійснюється для захисту прав потерпілого у кримінальному процесі.

Розглядаючи кримінальну процесуальну реституцію як спосіб відшкодування майнової шкоди, необхідно підкреслити натуральний характер відшкодування, оскільки саме в ньому знаходить свій прояв зміст цього способу.

Вказане визначення, на наш погляд, суперечить сутності реституції, у ньому втрачається іiі зміст, оскільки відбувається вже не відшкодування шкоди в натурі, а відшкодування шляхом виплати грошової компенсації, що «розмиває межі» між реституцією та цивільним позовом. Як слушно зазначає С.О. Александров, потерпілий за допомогою реституції отримує «своє», а не «замість» [10, c. 28].

Аналогічним чином це питання вирішується й у судовій практиці, де чітко розрізняються такі способи відшкодування шкоди потерпілому, як цивільний позов та кримінальна процесуальна реституція. 


\section{Кримінальне право, кримінальний процес та криміналістика}

Суди здебільшого використовують наступні словосполучення "достатність кримінально - процесуальної реституції виключає задоволення в цій частині цивільного позову», «цивільний позов задоволенню не підлягає, зважаючи на достатність кримінально-процесуальної реституції.

Хоча судді реституцію у кримінальному процесі переважно розуміють як повернення безпосередньо втраченого в результаті вчинення злочину майна, слід звернути увагу і на поодинокі випадки, що стосуються протилежного розуміння кримінальної процесуальної реституції органами суддівської влади.

Вважаємо, що такий підхід до визначення реституції в кримінальному процесі не відбиває суті цього поняття як окремого способу відшкодування шкоди потерпіломy.

Розглядаючи кримінальну процесуальну реституцію як спосіб відшкодування шкоди, слід вказати, що наразі в науці кримінального процесу точиться дискусія стосовно можливості застосування реституції для відшкодування потерпілому моральної шкоди. На думку окремих науковців, кримінальна процесуальна реституція в цьому випадку нереальна, оскільки моральну шкоду відшкодувати неможливо. Прихильники даної точки зору визначають відшкодування шкоди як повернення порушених благ у стан, в якому вони знаходилися до злочинного діяння. У цьому розумінні моральна шкода відшкодуванню не підлягає.

Досліджуючи процесуальний порядок застосування реституції, варто відмітити, що в чинному кримінальному процесуальному законодавстві відсутня правова регламентація процедури передачі майна потерпілому. Питання стосовно речових доказів наразі регулюються Порядком зберігання речових доказів стороною обвинувачення, їх реалізації, технологічної переробки, знищення, здійснення витрат, пов'язаних з їх зберіганням і пересиланням, схоронності тимчасово вилученого майна під час кримінального провадження від 19.11.2012 р. [11]. Аналізуючи згаданий документ, можна констатувати, що в ньому не встановлено порядку повернення речей потерпілому.
У даному аспекті варто зауважити, що здійснення відповідними посадовими особами реституції - це процесуальні дії, під час яких мають застосовуватися кримінальні процесуальні способи фіксації. У випадках, коли реституція слугує механізмом відшкодування шкоди потерпілому, це має знайти відповідне відображення в матеріалах кримінального провадження.

На практиці потерпілий надає розписку про отримання майна, однак, на наш погляд, розписка не може бути належним способом фіксації процесуальної дії. Відповідно до ст. 103 КПК процесуальні дії під час кримінального провадження можуть фіксуватися: у протоколі, на носії інформації, на якому за допомогою технічних засобів зафіксовані процесуальні дії, у журналі судового засідання.

Вбачається, що після приведення у відповідність до вимог чинного законодавства вона стане такою, що заслуговує на увагу та підтримку з огляду на наступне. Складення протоколу про повернення майна та фіксація за допомогою науковотехнічних засобів процесу передачі майна убезпечить потерпілого від несумлінного виконання посадовими особами своїх обов'язків та сприятиме відшкодуванню йому шкоди шляхом застосування кримінальної процесуальної реституції. Разом із тим запропоноване положення убезпечить державні органи від невиправданих скарг з боку потерпілого.

3 огляду на те, що наразі на рівні КПК не закріплено ефективних гарантій відшкодування потерпілому шкоди за допомогою кримінальної процесуальної реституції, пропонуємо ввести в КПК окрему статтю, яка регулювала 6 такі питання: поняття, предмет кримінальної процесуальної реституції та порядок ії здійснення.

Наведені вище законодавчі приписи(ч. 9 ст. 100 КПК) дозволяють констатувати, що часовими межами, в яких здійснюється реституція в кримінальному провадженні, є: час ухвалення судового рішення, яким закінчується кримінальне провадження, або винесення судом ухвали в разі закриття кримінального провадження слідчим або прокурором. 
Таке затягування із вирішенням питання про застосування кримінальної процесуальної реституції, на наш погляд, є необгрунтованим. Науковці 3 цього приводу пропонують застосовувати реституцію вже на початковій стадії кримінального провадження за наявності певних умов, а саме: якщо на об'єктах злочинного посягання відсутні сліди злочину та є клопотання потерпілого про повернення майна [12, с. 12].

Такий підхід до вирішення цього питання, на наш погляд:

- по-перше, не перешкоджатиме здійсненню подальшого кримінального провадження;

- по-друге, потерпілому буде надано можливість отримати відшкодування за спричинену йому шкоду якнайшвидше, не очікуючи судового розгляду кримінального провадження.

Цікавим вбачається підхід, який використав законодавець Республіки Молдова. Так, у КПК цієї держави окремо виділяються дві статті, які стосуються рішення щодо речових доказів, що виносяться до основного розгляду кримінальної справи, і рішення, що приймаються під час вирішення кримінальної справи по суті.

У цьому контексті слід додати, що до вирішення кримінальної справи прокурор або офіцер по кримінальному переслідуванню за згодою прокурора, або судова інстанція вирішують питання щодо повернення законному власнику його майна (ч. 1 ст. 161 КПК Республіки Молдова).

Згідно 3 ч. 2 ст. 161 КПК Республіки Молдова до вирішення кримінальної справи прокурор або офіцер по кримінальному переслідуванню за згодою прокурора на етапі кримінального переслідування, або, залежно від обставин, судова інстанція розпоряджається про повернення законному власнику: продуктів, що швидко псуються; предметів, необхідних у повсякденному побуті; домашніх тварин, птахів, інших тварин, які потребують повсякденного догляду; автомобіля або іншого транспортного засобу, якщо на нього не накладено арешт для забезпечення пред'явленого цивільного позову в кримінальній справі або в цілях можливої спеціальної конфіскації майна; громіздкі речі та інше.

Отже, у випадках, коли це необхідно, законодавець Республіки Молдова припускає можливість до вирішення справи по суті передати предмет кримінальної процесуальної реституції законному володільцю.

Чинний кримінальний процесуальний закон України передбачає, що речові докази, які не містять слідів кримінального правопорушення, у вигляді предметів, великих партій товарів, зберігання яких через громіздкість або 3 інших причин неможливе без зайвих труднощів або витрати по забезпеченню спеціальних умов зберігання яких співмірні з їх вартістю, а також речові докази у вигляді товарів або продукції, що піддаються швидкому псуванню, повертаються власнику (законному володільцю) або передаються йому на відповідальне зберігання, якщо це можливо без шкоди для кримінального провадження (п. 1 ч. 6 ст. 100 КПК). Як видно, така вказівка закону дає можливість власнику отримати своє майно до вирішення справи по суті тільки в обмеженому колі випадків.

\section{Висновки}

3 огляду на зазначене вище вважаємо, що варто впровадити в чинний КПК нормативний припис щодо можливості застосування кримінальної процесуальної реституції на стадії досудового розслідування (не стосується повернення швидкопсувних, громіздких та інших речей внаслідок закриття кримінального провадження слідчим або прокурором) за умов, якщо на об'єктах злочинного посягання відсутні сліди кримінального правопорушення та є клопотання потерпілого про повернення йому майна. Такі пропозиції дозволять потерпілому не очікувати на вирішення основного питання кримінального провадження - винуватості або невинуватості особи, та сприятимуть більш оперативному відшкодуванню шкоди.

\section{Література}

1. История законодательства СССР и РСФСР по уголовному процессу и организации суда и прокуратуры 1917 - 1954 гг.: 


\section{Кримінальне право, кримінальний процес та криміналістика}

сборник / под ред. С. А. Голунского; сост.ᄉ. Н. Гусев. Москва : Госюриздат, 1955. 635 с.

2. Нор В.Т. Защита имущественных прав в уголовном судопроизводстве: монография / В.Т. Нор. Киев : Вища шк., 1989. 275 c.

3. Карабан В.I. Англійсько-український юридичний словник. Вінниця: Нова Книга, 2004. 1088 с.

4. Діденко Є.В. Відшкодування збитків, завданих кримінальним правопорушенням, у кримінальному процесу України // Науковий вісник Національного університету державної податкової служби України. 2012. № 3 (58). С. $212-217$.

5. Федорчук Н.Б. Захист прав потерпілих від злочину в англо- американській правовій системі та кримінальному судочинстві України: монография / Н.Б. Федорчук,В.Т. Нор. Київ: Правова єдність, 2009. 192 с.

6. Шнайдер Г.Й. Криминология /Г.Й. Шнайдер; под общ. ред. А.О. Иванова. Москва : Б.и., 1994. 504 с.

7. Корякін Р.В. Реституція у сучасному кримінальному процесі України: автореф. дис. ... канд. юрид. наук: 12.00.09 / Р. В. Корякін. Київ, 2006. 20 с.

8. Понарин В.Я. Уголовно-процессуальная реституция // Известия Высших учебных заведений. Правоведение. 1988.№ 1 . С. $43-47$.

9. Зинатуллин 3.3. Возмещение материального ущерба в уголовном процессе / 3.3. Зинатуллин. Казань: Изд-во Каз. ун-та, 1974. 99 с.

10. Александров С. Уголовно-процессуальная реституция // Советская юстиция. 1990. № 5. С. $28-29$.

11. Порядок зберігання речових доказів стороною обвинувачення, їх реалізації, технологічної переробки, знищення, здійснення витрат, пов'язаних з їх зберіганням і пересиланням, схоронності тимчасово вилученого майна під час кримінального провадження від 19.11.2012 р. № 1104 // Офіційний вісник України. 2012 р. № 91. С. 62.Ст. 3697.
12. Шаповалова ᄉ.I. Потерпілий як суб'єкт кримінально-процесуальної діяльності в досудових стадіях кримінального процесу: автореф. дис. канд. юрид. наук: 12.00.09 / ^.І. Шаповалова. Київ, 2001. 18 с.

\section{Tsyliuryk Inna \\ GRIMINAL PROGEDURAL RESTITUTION AS A METHOD OF COMPENSATION TO THE VICTIM OF DAMAGES GAUSED BY CRIMINAL OFFENSES}

The article considers the concept of "restitution" as a way to compensate the victim. It is determined that the current CPC does not provide a definition of this concept, but we emphasize that restitution as a way to compensate the victim was enshrined in law in the first legal acts of the Soviet state. That is why restitution is the simplest way to protect the violated property rights of the victim. With its help, the legislator expects to promptly restore the property status quo, in which the person was before the crime against him. The term "restitution" has found its normative consolidation at the level of international documents. The declaration contains a separate section (Articles 8 - 11) on restitution. According to Art. 8 of the Declaration, restitution should include restitution of property or compensation for damages, reimbursement of costs incurred by victimization, provision of services and restoration of rights. equivalent of destroyed property. The approach used by the legislator of the Republic of Moldova is interesting. Thus, the CPC of this state has two separate articles, which relate to decisions on material evidence submitted to the main trial of a criminal case, and decisions taken during the resolution of a criminal case on the merits.

This suggests that the current CPC should introduce a normative provision on the possibility of criminal procedural restitution at the stage of pre-trial investigation, provided that there are no traces of a criminal offense at the objects of criminal encroachment and there is a request of the victim to return his property.

Keywords: restitution, criminal offense, task damage, victim, property. 